\title{
An Assessment of Groundwater Grab Syndrome in Langata Sub County, Nairobi City-Kenya
}

\author{
E. A. Ochungo' ${ }^{1}$ G. O. Ouma ${ }^{2}$, J. P. O. Obiero ${ }^{3}$, N. A. Odero ${ }^{4}$ \\ ${ }^{1}$ Institute for Climate Change and Adaptation (ICCA), University of Nairobi, Nairobi, Kenya \\ ${ }^{2}$ Department of Meteorology, University of Nairobi, Nairobi, Kenya \\ ${ }^{3}$ School of Engineering, University of Nairobi, Nairobi, Kenya \\ ${ }^{4}$ Department of Electrical and Electronics Engineering, Machakos University, Machakos, Kenya \\ Email: elishakech1@gmail.com
}

How to cite this paper: Ochungo, E.A., Ouma, G.O., Obiero, J.P.O. and Odero, N.A. (2019) An Assessment of Groundwater Grab Syndrome in Langata Sub County, Nairobi City-Kenya. Journal of Water Resource and Protection, 11, 651-673. https://doi.org/10.4236/jwarp.2019.115038

Received: April 23, 2019

Accepted: May 28, 2019

Published: May 31, 2019

Copyright $\odot 2019$ by author(s) and Scientific Research Publishing Inc. This work is licensed under the Creative Commons Attribution International License (CC BY 4.0).

http://creativecommons.org/licenses/by/4.0/

\section{Open Access}

\begin{abstract}
Interest on the investigation of groundwater depletion threat is growing globally and Langata sub County in Nairobi, the capital city of the Republic of Kenya, is not an exception. Because of drought-induced water shortage, households in Langata do rely on borehole water to augment their intermittent municipal water supply system. Consequently, there is an upsurge of borehole developments as drought events unfold. Previous studies here have focused on impact of borehole depths and density yet little seems to have been done to compute the correlation coefficient between drought events data and historical borehole development records as an assessment for groundwater "grab" syndrome. This study used drought index computation method (SPI) alongside other statistical methods to seek the answer to the problem. Using 57 years of monthly rainfall data and 26 years of borehole development data, the study established that, there is a positive correlation coefficient. Similarly, a trend analysis of borehole drilling and struck water level depths indicated a positive parallel rising trend on both. Further, when the borehole distribution map and struck water level contour maps were plotted, a sign of a probable well interference during pumping was detected, which however, requires a new investigation to confirm the syndrome of groundwater depletion threat. The study has contributed to the groundwater depletion research by deploying statistical research methods for risk detection. Finally, the study has proposed for a new groundwater management policy that will encourage initiation of artificial recharge schemes for the study site and beyond.
\end{abstract}

\section{Keywords}

Drought, Groundwater, Depletion and Sustainability 


\section{Introduction}

Interest on groundwater resource management studies is growing due to the ongoing climate and anthropogenic changes [1]. The sub Saharan Africa region's aquifers are considered to be the most vulnerable to the negative impacts of the prevailing climate change [2] [3]. The impacts are known to cause droughts that always hamper the natural renewal of groundwater resources in storage aquifers. This in return, ends up increasing the risk of water scarcity [4], which in fact, is a global challenge. For example, worker in [5] reports that, groundwater in urban areas and industrial zones in India are far beyond their safety limits due to a fast rising demand for water. Equally, [6] talks of groundwater being an important buffer to drought challenge in sub Saharan Africa especially for cities. The only intriguing matter is that, the resource is invisible which poses a management challenge in the words of [7]. Regions like Brazil, China and South Africa are particularly known to face chronic groundwater depletion threat [8] [9].

Previous investigations on aquifer groundwater depletion have mostly focused on the recharge perspective [10] as reviewed by [11]. However; little information exists on the illustration of an existing correlation between drought events in an area and the likely syndromes or tell-tale signs showing a tendency towards overexploitation of the area's aquifer. Accordingly, this study aims to assess if there is a correlation coefficient between drought events and groundwater development trend in Langata sub County see Figure 1(a) and Figure 1(b).

Groundwater is broadly defined as the water present in the zone of saturation below the ground. Of the 37 million $\mathrm{km}^{3}$ of freshwater estimated to be present on the planet earth, about 22\% exists as groundwater [12] [13]. Earth's reserve of groundwater is threatened everywhere according to [14] [15] because water is at the centre of all sustainable development endeavors [16]. It is reported that about 1.7 billion people live in areas which are already been threatened by water shortage [17] even as we know the global population is increasing by 74 million per year [18].

There are two types of aquifers; deep and shallow. To exploit water from deep aquifers, boreholes or tube wells are drilled into the earth to allow for pumping onto the surface of the targeted freshwater. On the other hand, shallow aquifers' water is extracted using wells [19]. More than 300 million wells have been drilled for water withdrawal in the world in the last three decades, and about one million wells are drilled annually in the USA alone according to [20]. When groundwater abstraction exceeds the natural groundwater recharge, then we talk of an overexploitation or persistent groundwater depletion phenomenon [21].

The drivers to groundwater depletion are majorly attributed to drought episodes like the cases of Colorado River Basin [22] and in Bangladesh [23] [24] just as examples. Other scholars like [25] also report that virtual groundwater transfers through trade in cereals have as well led some aquifers to face depletion threat in the United States. Further; available information indicates that groundwater over-abstraction is a major emerging problem in many other parts of the 
world [26]. In fact, in some regions, it is severe and water levels are declining at rates of about $1 \mathrm{~m}$ to $3 \mathrm{~m} /$ year, a pattern documented by many researchers like [27] [28] [29].

World leaders are concerned with the continuing propagation of the groundwater depletion threat. And so, one of the top most agenda items up in their sleeves, is the management of the groundwater vulnerability [15]. For example, in the year 2000, various UN organizations launched collaborative pollution assessment activities in several African cities' groundwater [30] whose central focus was the promotion of the sustainable use of the exploitable reserves [31].

The urgency for a responsible water use is exacerbated by the fact of our knowledge that population pressure is growing specifically in cities which calls our attention to relook a fresh on the urban water security debate [32]. Excessive groundwater depletion currently affects major regions of North Africa, the Middle East, South and Central Asia, North China, North America, and Australia as well as localized areas throughout the world [33]. The key concern is how to maintain a long-term sustainable yield from aquifers [34] [35].

\section{Background}

\subsection{The History of Sustainable Groundwater Development}

The oldest water well (which is about 8000 years) is in Atlit-Yam village in northern Israel according to [36]. Since then, man has uncontrollably enjoyed groundwater. Because of the need for control, sustainability concept came into being [37]. The concept advocates strongly for an intergenerational equity. It points to the interdependence between economy and natural environment and the conservation of the natural capital, and it calls the attention on irreversible damages and improved management devoid of overexploitation.

It is this aspiration that made [34] to define ground-water sustainability as development and use of ground water in a manner that can be maintained for an indefinite time without causing unacceptable environmental, economic, or social consequences. The definition was founded on the history of groundwater development as sketched by [38] and later amplified by pioneer workers like [39] [40] [10] and [41]. Majority of the scholars concurred that water balance must be maintained between discharge and recharge of any river basin for ecosystem and human development to coexist sustainably.

The concern on unsustainable groundwater development has been traced from 1900 by [42]. And it has been found to be particularly severe for the transboundary aquifers [43]. The overexploitation of such aquifers has led to the declining of well yields, drying up of springs, stream flow depletion, and land subsidence. In many instances, this has brought degradation of groundwater quality by natural and/or anthropogenic pollutants and by saltwater intrusion which have all ended up in the threatening of our ecosystems and even the life of our future generations. On a broader scale, some communal conflicts have been witnessed in most of the 240 transboundary aquifers that have been mapped across 
the world due to overexploitation [44]. Similar issues have been recorded for arid and semi arid regions [45].

Overexploitation is a term that is generally used to point out negative aspects of groundwater development [46]. There is a general lack of consensus as to what exactly constitutes overexploitation based on the interpretation of the information at hand and the prevailing societal hydro-myths [47]. Strict overexploitation is produced when abstraction is greater or close to recharge [48]. Nevertheless, even in this case, the evolution-such as progressive groundwater head drawdown and water quality deterioration, reflected in increasing water winning cost and water availability reduction-is what finally is used to qualify the situation [49] [50] [51]. But the bottom line is, groundwater exploitation and mining must involve ethical considerations, as do the exploitation of other natural resources and the environment, as stated by [52]. Through this mindful observation of safe yield, water can be withdrawn without producing undesirable effects such as reservoir exhaustion, excessive pumping costs or water quality deterioration [50].

\subsection{The Situational Analysis of the Study Site}

Langata (Figure 1(a) and Figure 1(b)) is one of the 17 administrative units of Nairobi City County, Kenya. It has five administrative wards, namely; Karen, Langata, South C, Nairobi West and Nyayo Hihrise. It covers $196.8 \mathrm{~km}^{2}$ with 176,314 residents in 52,656 households. Generally, it enjoys a temperate tropical climate throughout the year [53]. Because of drought, municipal water is intermittent and so majority of residents have turned to "grabbing" groundwater to cope with the shortage. By "grabbing", we mean, the uncontrolled steep proliferation of borehole numbers in the last few decades making the situation look like there is a scramble to own a borehole by most property owners for alternative water supply sources [54]. Even the city's metropolitan regions like Ngong area depends exclusively on the Nairobi Aquifer System's groundwater as reported by [55]. It is important to note further, that the proliferation of boreholes numbers

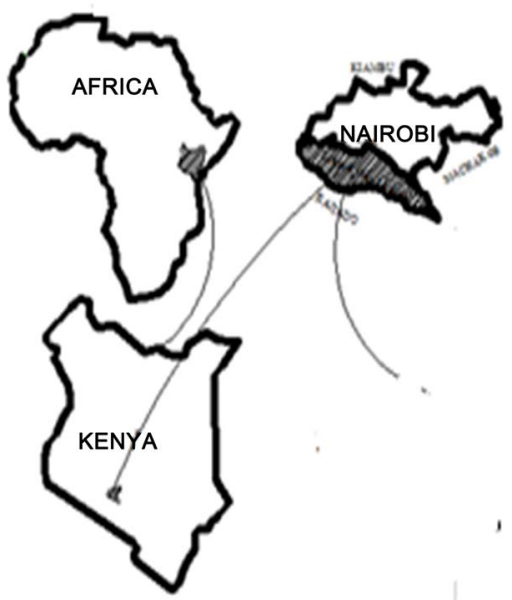

(a) 


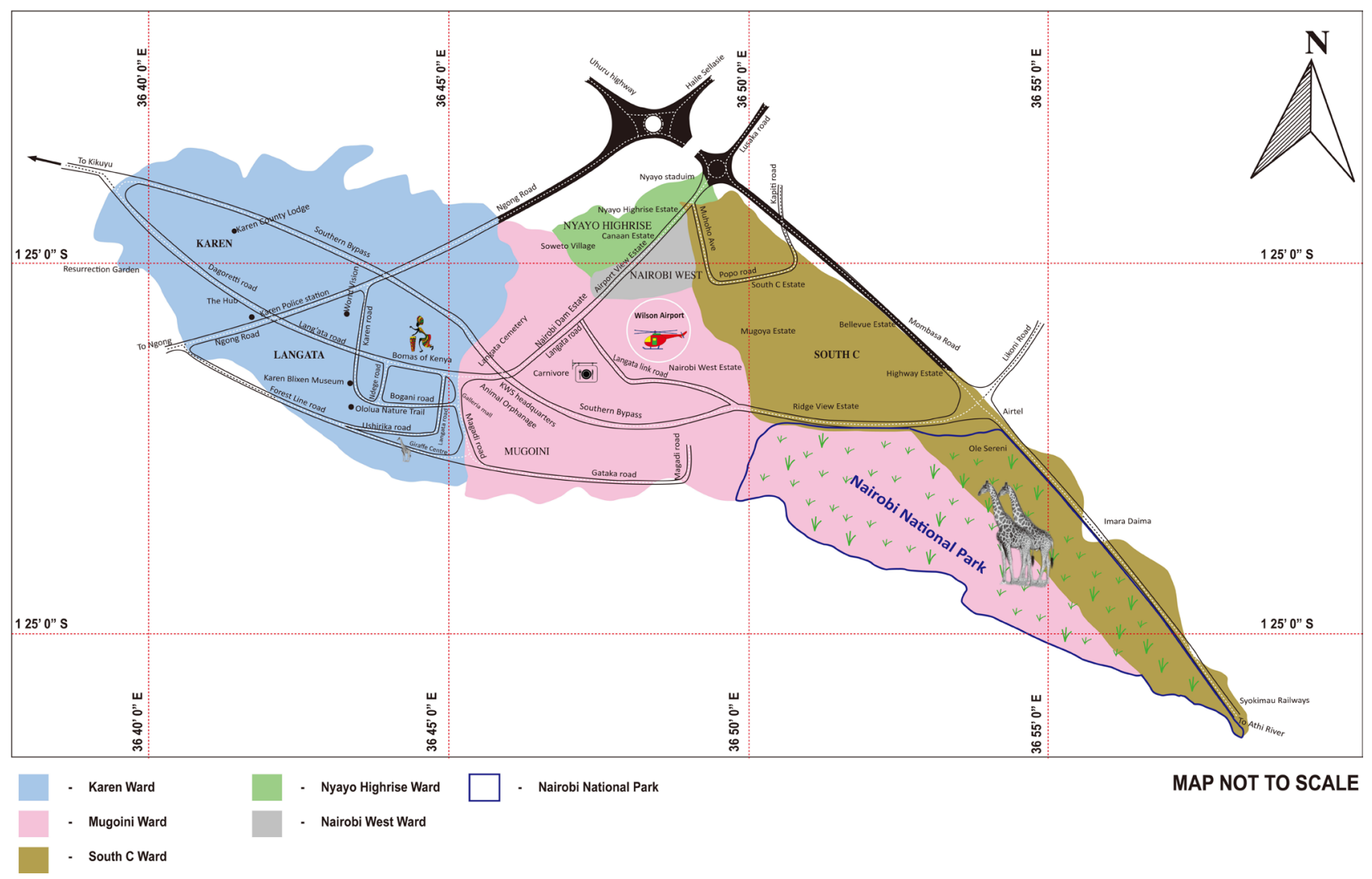

(b)

Figure 1. (a). Map of Africa, Kenya and Nairobi City County (NTS). (b). Location map of Langata sub County to the south of Nairobi city centre. 
of which, only $40 \%$ receive water on a 24 -hour basis, the rest are on official rationing program. According to the Nairobi City Water and Sewerage Company (NCWSC), the estimated demand for the residents of Nairobi in the year 2010 was $650,000 \mathrm{~m}^{3}$ per day while the supply stood at only $482,940 \mathrm{~m}^{3}$ per day. The government has embarked on creating new water policies to protect water catchment areas, reduce pollution and enhance access to clean water [58].

Studies on Nairobi's groundwater depletion has a long history as chronicled by [59] in the hydrogeology report of Nairobi area. Most recently, [60] used hydro-geological data obtained from drilling records to estimate the ground settlement for the period between 1927 and 2009. They reported that the number of boreholes for abstracting water from aquifers beneath Nairobi city increased from 2 in the year 1927 to about 2500 in the year 2009 consistent with the population growth from 29,864 in 1928 to $3,138,295$ in 2009. Substantial groundwater drawdown had been noted in individual boreholes that supply the growing population in some localities of the city but at a price.

The study warned that, the groundwater rest levels have dropped with an average of $79 \mathrm{~m}$ and a probable settlement of $0.34 \mathrm{~m}$ to $5.9 \mathrm{~m}$ which is a sign of groundwater depletion from the aquifers. Two thirds of the well development happened in the last two decades in which over 1000 tube wells were drilled in the city. This same concern was affirmed in a recent study by [61], the Head of Department of Geology, University of Nairobi. He used analysis of the groundwater level monitoring data to assess depletion threat. His results indicated that the decline of water rest levels of boreholes in Nairobi and its environs is worrisome and needs an urgent fixing especially for Karen area.

Similar studies on water resource degradation have been done on a national scale but with contributions touching on Nairobi Aquifer System. For example, a literature review study by [62] reported that Nairobi depends on groundwater drawn from the Nairobi Aquifer Suite, which covers an area of approximately $3000 \mathrm{~km}^{2}$. The study asserted that, a proper groundwater harnessing in Nairobi city started in the early 1950s, adding that by the year 2002, the city had 1350 boreholes supplying about seven thousand cubic meters per day (21\% of the city's daily water demand) as later affirmed by [63].

Using the same method [64] undertook to paint the role of groundwater in the water-supply of Greater Nairobi. The study confirmed that the bulk water system for the city is not reliability due to drought risk. However, it added that, groundwater is the default alternative, a practice that began in the 1930s.By 2005 , the report added, about $85,000 \mathrm{~m}^{3}$ /day (equivalent to $25 \%$ of single day city's water demand) was being withdrawn from city's groundwater. Further, the same authors stated that by 1940 , the city had only 10 boreholes increasing to 2000 by 1997 and 2250 by 2001 due to drought-induced water shortage. They concluded that, groundwater level observation and monitoring system for the city was established in the 1950s. From the same, Langata area data had shown 4 - $5 \mathrm{~m}$ level decline during 1970-1975 reporting period. 
The vulnerability of Nairobi Aquifer System has also been studied using well interference formula by [65] who established that proximity showed a $6 \%$ increase in the number of boreholes that lie within $100 \mathrm{~m}$ from each other from 2011 to 2013, a claim repeated by [61]. Secondly, the analyses on drilling depths indicated that an average increase of $170 \mathrm{~m}$ from 1930 to 2013 and this was attributed to pollution of the upper aquifer and potentially competition for groundwater. Other notable findings in their work included; low level of compliance mainly driven by the county's population increase which drives other exigent contributing factors like; increased water demand; intermittent piped supply; unclear legal framework; poor enforcement of supportive regulations; lack of a publicly available groundwater database for decision making; low capacity of the regulator; apparent groundwater availability that allows errand drillers to forego due processes, and low level of awareness of residents and borehole owners.

On his part, [66] assessed through modeling the potential disaster sites within the city of Nairobi using geographic information system (GIS). He analyzed the superimposed geological, topo-cadastral, seismic data (1994-1999) obtained from the geology department of the University of Nairobi to identify faultines. The results indicated that the faultlines are affecting a good number of plots in the western side of Nairobi including the prime areas of Karen and Langata. He concluded that those two areas are prone to earthquakes as per the distribution of earthquake points in Kenya.

\section{Related Work}

The debate on groundwater sustainability began in the early $19^{\text {th }}$ century as documented by [67]. And by about 1970s; the concern peaked and focused on the cost of pumping as recorded by [68]. For cities, management of risks in the urbanizing Anthropocene is one of the greatest challenges today. Decisions on adaptive pathways and choice of coupled infrastructure can sometimes result in unintended consequences. Most of the time when addressing one vulnerability within a connected system, chances are that the solution can in fact create a new kind of risk to the same system if not well thought through, like in the water cycle pathways narration on Mexico City [69].

Assessing groundwater depletion threat has attracted very many investigators. The interest is borne out of the fact that, use and misuse of water in one location can have far-flung effects, altering downstream resources, affecting the reliability of water flows, and degrading water quality and aquatic ecosystems as observed by [70]. In 2011 [71] for example, used a water table fluctuation method to assess the impact of intensive groundwater abstraction on recharge to shallow aquifer system in Bangladesh. This quantitative method confirmed that, the then ongoing groundwater abstraction for irrigation and urban water supplies was unsustainable.

In the same year worker in [42] used literature analysis method to investigate the contribution of the global groundwater depletion since 1900 to sea-level rise. This study found that between 1900 and 2008, groundwater depletion had 
caused a $12.6 \mathrm{~mm}$ sea level rise and that the rate increased from the year 1950. In South Africa, [43] applied the same method as Konikow to conduct a critical overview of shared transboundary aquifers. This South African study established that $96 \%$ of the shared aquifers were low yielding despite the fact that water demand in the area was on the rise.

Other scholars like those in [72] have used scenario analysis method to quantify the anthropogenic stress on groundwater resources in Iran, California and Germany comparatively. The study showed that reduced human withdrawals could help with regime change in some aquifers adding that there is a trending threat to the sustainability of groundwater in northwest Iran and California. This, they further advised, needed a more careful assessment and monitoring practices as well as strict regulations to mitigate the negative impacts of groundwater overexploitation. The authors have used the case of California; a state billed as America's salad bowl, to hammer home an important message to the world on how to respond to drought. The study concluded that, California's historical drought events of 1976-77, 1988-92 and the 2007-09 etched water management legacies like; conservation schemes, water markets, drought water banks of the 1990s, water sale between users and water transfer schemes. In fact, up till recently, the vulnerability of the state of California to both drought and groundwater depletion risks caused [73] to sound a profound warning. The latter stated that California community must, as a matter of urgency, quickly learn to live with its dry climate to manage a looming desert at the edge of Cathedral City.

Groundwater issues have for a long time been left in the hand of geologists and engineers, but with the growing interest today, this is bound to change to remove the existing knowledge as symmetry. Using knowledge expansion lens and case studies in countries with intensive groundwater development, [74] proposed that; direct regulation, indirect policy levers, livelihood adaptation and people's participation are needed to simultaneously improve governance. This same concern saw [75] call for a sustainable groundwater development and management in Hang-Jia-Hu Quaternary Plain. This was in response to an ongoing degradation of what was once billed as China's "fish and rice field". The plunder eventually led to significant aquifer water level deterioration.

Generally, irresponsible natural resource utilization continues to heat up the minds of researchers. For instance, Jared Diamond's 2005 metaphor "collapse" of Rapa Nui (Easter Island) or self induced "Ecocide" [76] has been used by many scholars like [77] to trumpet a call for change. Rapa Nui was once a promising forested island with fertile soils, but because of human greed, it has become a desert with statues erected as trees' substitutes. Sadly, according to the world famous anthropologist; Jared Diamond, Easter Island today cannot support life.

Another case of plunder is the Berkeley Pit; the eyesore that today defines the feature of Butte, Montana's landscape [78]. This was once a booming copper mining site that was full of urban life. But because of unsustainable open pit mining, the pride has turned into an acid lake out of the former mining pit just like 
depletion of California's geothermal geysers [79]. These examples from Rapa Nui and Butte, Montana serve as classic reminders to us on how a boom in resource extraction can lead to a bust and finally to a permanent damage. Based on such conclusions, we are here raising a red flag on groundwater resource use in Langata sub County in the same manner workers in [80] did for Kairouan plain aquifer in central Tunisia. Additionally; in Northwestern Sahara Aquifer System workers in [81] had given a similar warning.

The costs of resource depletion externalities when it comes to groundwater depletion are varied. In irrigated agriculture sector, farmers may experience economic losses due to poor harvest, which use of tank storage can reduce [82]. Land subsidence is another danger as mentioned for the case of Xixi-Chengnan area in Jiangsu Province, China as reported by [83]. In general terms, experts advise that groundwater use in any area must be within the ecological carrying capacity [84] to avoid onset of irreversible consequences. That is why the success of Barind rural groundwater irrigation scheme in Northwest Bangladesh has always remained a shining example of a sustainable groundwater use from 1985 when it was established [85].

In Langata sub County, however, there is a rapid rate of tube wells drilling which must be changed if the eminent subsidence risk, as sounded by [66] is to be avoided. This is in line with admonition given by [86] that action to help urban communities in adapting to climate change must be sustainable. Drawing from this and the above literature analysis, it appears vividly that, there is no information on the relationship between drought events and tube wells drilling. The existing conceptual models for assessment of groundwater depletion seem to be varied in scale and type with majority of previous investigators using either review methods, vulnerability frameworks as was postulated by [87], scenario analysis and/or modeling including vulnerability map plotting.

On our part, we deployed a mix of analytical method (statistical) and vulnerability map plotting approaches. We settled on correlation analysis borrowing from the work by [88] who conducted analysis on groundwater quality with respect to coloration in Akuapem North Municipality in the Eastern Region of Ghana which faces inadequacy of water supply and groundwater is a common alternative. The correlation coefficients between paired parameters; conductivity, turbidity, coloration, iron, manganese, $\mathrm{pH}$ and temperature were computed.

In our case, we illustrated the correlation coefficient between annual drought events in the area and the corresponding annual borehole drilling for the period between 1982 and 2017. We began by estimating drought events using drought index formula known as Standard Precipitation Index (SPI) as designed by [89] and later adopted by World Meteorological Organization (WMO) in 2009. In 2011, (SPI) again received another global endorsement at the International Workshop on Drought and Extreme Temperature in Beijing China which was dubbed Lincoln declaration on drought indices [90]. From the drought events plot graph, years with drought were identified. An excel table of drought years and corresponding boreholes was prepared. 
This was followed by conducting statistical analysis on annual drought event and annual boreholes commissioned. We closed by plotting the distribution maps of the boreholes, their depths and contour of the struck water levels over the area. The results may help coordinate the local community to adopt a sustainable groundwater management system hinged on an equitable freshwater sharing from the already existing boreholes. Our theoretical contribution in the groundwater management literature is the use of correlation analysis between drought events and human responses. The resulting correlation coefficient is to represent the degree of linear association between two variables [91]. The outline of rest of the remaining sections is as follows; 4 describes the method, 5 shows results and discussion while 6 is the conclusion.

\section{Method}

\subsection{Study Area}

Langata is about 10 kilometers to the south of city center. It is located at approximately $1^{\circ} 22^{\prime} 0$ "S, $36^{\circ} 44^{\prime} 0^{\prime \prime} \mathrm{E}$. Its topography height range is between $1600 \mathrm{~m}$ to $1850 \mathrm{~m}$ above mean sea level. See location map and additional details in section 3 above.

\subsection{Data}

The monthly rainfall data for the period 1957 to 2013 was sourced from Wilson Airport; Kenya Meteorological Service station number: 9136130 at altitude 1638 $\mathrm{m}$ (a.s.l), located approximately $4 \mathrm{~km}$ to the south of Nairobi city center. The station is chosen because it is within the study site. Borehole commissioning data for the years 1982 to 2017 were obtained from Water Resources Management Authority, the body mandated by law as the overseer of Kenya's water resources. From these two sets of data, a table of; drought events, average struck water levels and borehole numbers per year were prepared.

\subsection{Identification of Drought Events Using Standard Precipitation Index}

For drought year identification, the monthly rainfall data for the period 1957 to 2013 (57 years) was sourced from Wilson Airport; Kenya Meteorological Service station number: 9136130. The Standard Precipitation formula was used to characterize drought;

$$
\mathrm{SPI}=\frac{X_{i}-\bar{X}}{\sigma}
$$

where $X_{i}$ is the annual rainfall of the $i$-th year and $\mathrm{X}$ bar is the mean annual rainfall over the full period. SPI values range between -2 and 2 with 0 being the turning point between wetness and dryness. The values below zero indicate drought years. In Figure 2, $x$ axis is time in years and $y$ axis is plot of wetness and dryness. The bars above zero indicate wet years and bars below zero line are the drought years. 


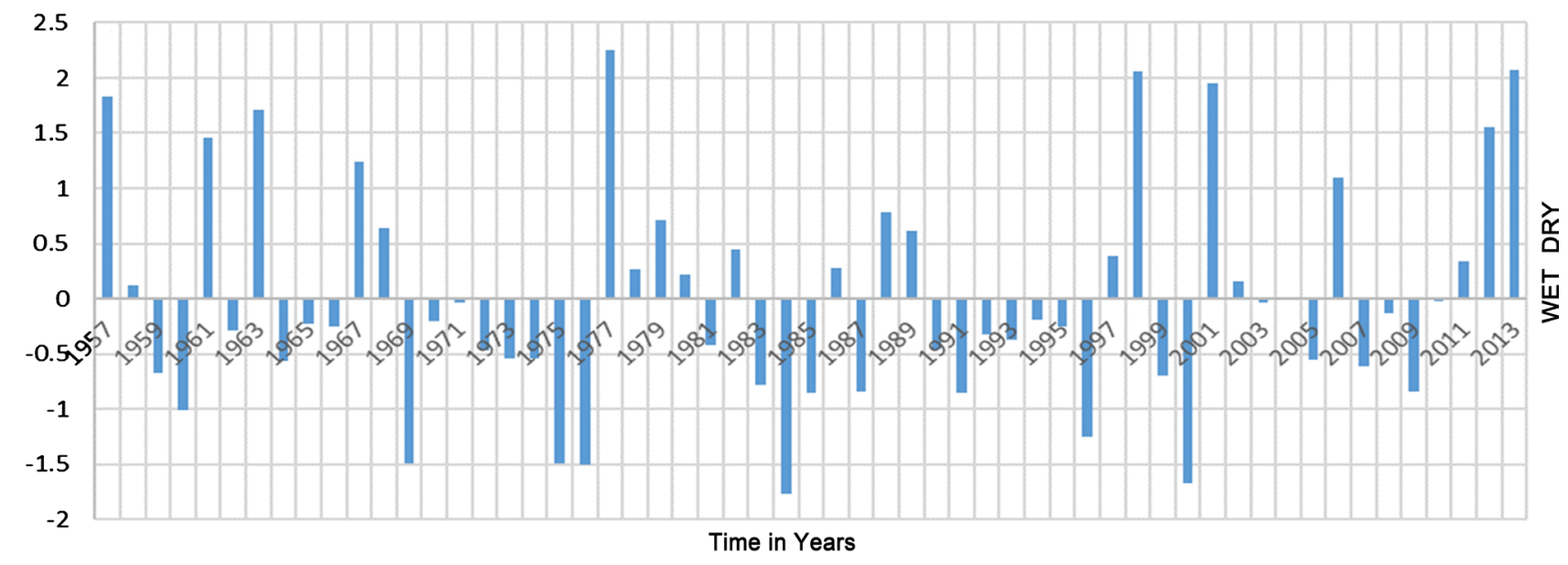

Figure 2. Identified drought years.

\subsection{Statistical Analysis}

To find correlation coefficient between drought events and groundwater development, consider a year's drought event as $X$ and the number of boreholes drilled in the same year as $Y$. The number of years with available data is taken as the sample size $\mathrm{n}$ as illustrated in [92]. The following eight steps were followed;

Computing the mean;

The mean $(\bar{x})$ is computed as the sum of all data values $X_{i}$, divided by the sample size $n$

$$
\begin{aligned}
& \text { Mean of } x_{i}-x_{n}=\frac{\sum x_{i}-x_{n}}{n}=\bar{x} \\
& \text { Mean of } y_{i}-y_{n}=\frac{\sum y_{i}-y_{n}}{n}=\bar{y}
\end{aligned}
$$

Computing the standard deviation;

They are computed using the squares of deviations of data from the mean

$$
\begin{aligned}
& \left(x_{i}-\bar{x}\right),\left(x_{i}-\bar{x}\right)^{2} \text { and } \sum\left(x_{i}-\bar{x}\right)^{2} \text { then } \frac{\sum\left(x_{i}-\bar{x}\right)^{2}}{n-1} \text { and } \\
& \sqrt{\frac{\sum\left(x_{i}-\bar{x}\right)^{2}}{n-1}}=d_{x} \\
& \left(y_{i}-\bar{y}\right),\left(y_{i}-\bar{y}\right)^{2} \text { and } \sum\left(y_{i}-\bar{y}\right)^{2} \text { then } \frac{\sum\left(y_{i}-\bar{y}\right)^{2}}{n-1} \text { and } \\
& \sqrt{\frac{\sum\left(y_{i}-\bar{y}\right)^{2}}{n-1}}=d_{y} \\
& \text { Compute new variables } Z_{x i} \text { and } Z_{y j} \text {. }
\end{aligned}
$$

$$
\begin{aligned}
& Z_{x i}=\frac{x_{i}-\bar{x}}{d_{x}} \\
& Z_{y i}=\frac{y_{i}-\bar{y}}{d_{y}}
\end{aligned}
$$

Compute product of new variables; 


$$
Z_{x i} \times Z_{y i}
$$

The following algebraic expressions then are used for computing the correlation coefficient $r$ and coefficient of determination $r^{2}$; the product $\left(Z_{x i}\right)$ and $\left(Z_{y i}\right)$, product of summation of $\sum Z_{x i}$ and $\left(Z_{y i}\right)$. The the correlation coefficient $r$ is then given by; $\frac{\sum Z_{x i} \times Z_{y i}}{n-1}$ whose square gives the coefficient of determination $r^{2}$. Further, correlation coefficient can be described as: small correlation-0.10 $=r=$ 0.29 , medium correlation $-0.30=r=0.49$ and large correlation $-0.50=r=1.0$ as described by [93]. A positive correlation indicates an increase in one variable associated with an increase in the other. The coefficient of determination $R$ is computed to show how the changes in one variable are explained by the changes in the other variable. It is simply the square of the coefficient of determination $\left(r^{2}\right)$. And it can be converted to percentage by multiplying by 100 .

$$
\left[\frac{\sum Z_{x i} \times Z_{y i}}{n-1}\right]^{2}
$$

Convert $r^{2}$ to percentage;

$$
\left[\frac{\sum Z_{x i} \times Z_{y i}}{n-1}\right]^{2} \times 100
$$

Finally using the drought and borehole data values, a graphical plot of the trend was drawn using values is Table 2 to produce Figure 3.

\subsection{Plot of Borehole Distribution Characteristics in the Study Site}

A study by [94] on borehole distribution in Awka urban area in Nigeria used two statistical analysis methods namely; nearest neighbor and quadrant analyses. The results showed irregular siting of boreholes that caused overcrowding around water points. Consequently, they advised that water boreholes should be sited in a regular manner as much as possible. In Nairobi's Westland sub County, scholars in [65] used geographic information system software to plot borehole proximity

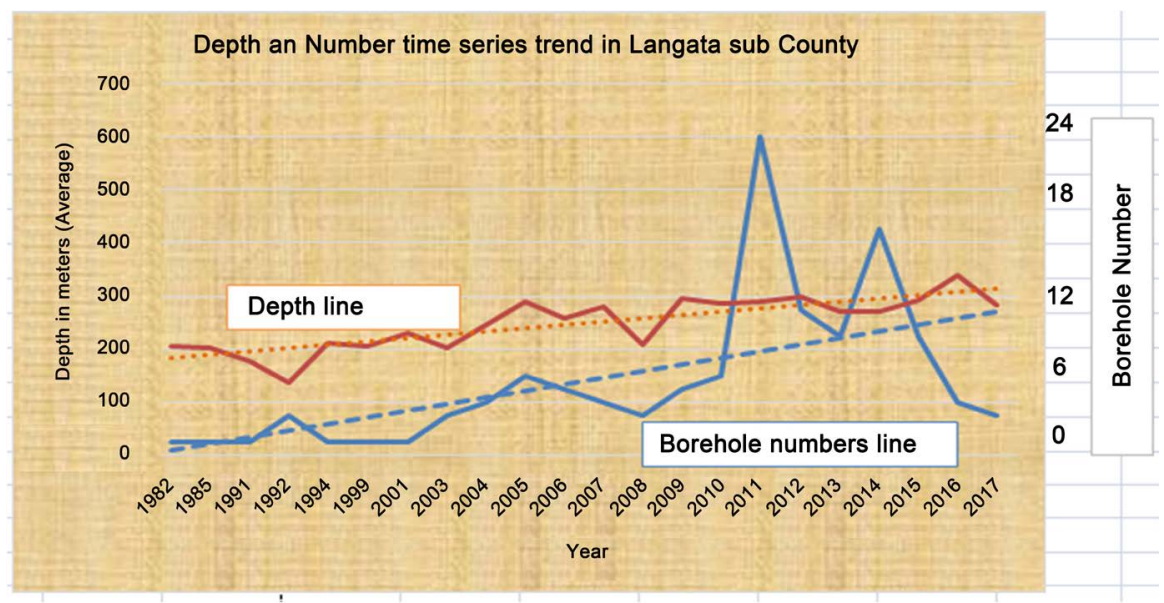

Figure 3. Trend analysis diagram. 
maps and found that many boreholes could possibly be causing well interference during pumping operations. In our case, the individual borehole data with spatial identity coordinates in the form of Northing, Easting and struck water levels (represented as $x, y$ and $z$ coordinates-connected to the National Grid System (UTM) formed the primary information for plotting of various vulnerability themes. We then deployed Eagle Point design software and AUTOCAD to produce; contour map of struck water levels and borehole distribution map from the single processed digital terrain model (DTM).

\section{Results and Discussion}

\subsection{Identification of Drought Events Using SPI}

The 1957-2013 rainfall data when analyzed using Equation (1) indicated that out of 57 rainfall years, 34 years were dry (59.65\%) with the driest being 1985 and 2011. See the graphical plot of SPI per year as in Figure 2. The borehole data available were from 1982 to 2017. The drought data were extrapolated from 2013 to 2017. This extrapolation was due to the lived experienced of the researchers having witnessed Kenya government declare each of the next years beyond 2013 drought years.

\subsection{Statistical Analysis}

From Figure 2 we were able to assemble a total of 36 years of data for statistical analysis in MS Excel using Equations (2) to (6), see Table 1. The coefficient of correlation is a positive one. The value of 0.117 falls within the first envelope of classification by [93] which means it is a small type. However the coefficient of determination of $11.71 \%$ does send to us a message that for every drought event within the study site, there a near $12 \%$ probability of a property owner drilling a borehole.

\subsection{Trend Analysis}

Using information in Table 1 and data from Water Resource Management Authority, we developed Table 2. From the table we plotted the trend analysis diagram between borehole number proliferation over the years and average water struck level see Figure 3 next to Table 2. From the 36 years' data as shown in Table 2, there were 26 drought events and 122 boreholes were dug (see Table 1) in the study site during the same period to cope with resulting water shortage. The year 2011 had the severest drought on the SPI scale (see plot in Figure 2). Interestingly and in a dramatic manner, it also registered the highest number of boreholes at 24 over the period. In terms of the trend, one would say, for every drought event, two boreholes were sunk (see the two trend lines in Figure 3 and their near parallel upward gradients). A striking inference out of this plot as can be viewed from the trend graph is the gradient of struck water level decline in the area as the numbers of boreholes are increasing. The more boreholes are drilled, the deeper it is to reach yieldable water. This reciprocally means two 
E. A. Ochungo et al.

Table 1. Statistical analysis.

\begin{tabular}{|c|c|c|c|c|c|c|c|c|c|c|c|c|c|c|}
\hline Year & $\begin{array}{c}X_{i} \\
\text { Drought }\end{array}$ & $\begin{array}{c}Y_{i} \\
\text { Boreholes }\end{array}$ & $x_{i}-\bar{x}$ & $y_{i}-\bar{y}$ & $\left(x_{i}-\bar{x}\right)^{2}$ & $\left(y_{i}-\bar{y}\right)^{2}$ & $n$ & $d_{x}$ & $d_{y}$ & $Z_{x i}$ & $Z_{y i}$ & $Z_{x i} \times Z_{y i}$ & $r^{2}$ & $R$ \\
\hline 1982 & 0 & 1 & 0.72 & 2.39 & 0.52 & 5.71 & & & & 3.5 & 0.09 & 0.31 & & \\
\hline 1983 & 1 & 0 & -0.3 & 3.39 & 0.08 & 11.5 & & & & -1.3 & 0.13 & -0.2 & & \\
\hline 1984 & 1 & 0 & -0.3 & 3.39 & 0.08 & 11.5 & & & & -1.3 & 0.13 & -0.2 & & \\
\hline 1985 & 1 & 1 & -0.3 & 2.39 & 0.08 & 5.71 & & & & -1.3 & 0.09 & -0.1 & & \\
\hline 1986 & 0 & 0 & 0.72 & 3.39 & 0.52 & 11.5 & & & & 3.5 & 0.13 & 0.44 & & \\
\hline 1987 & 1 & 0 & -0.3 & 3.39 & 0.08 & 11.5 & & & & -1.3 & 0.13 & -0.2 & & \\
\hline 1988 & 0 & 0 & 0.72 & 3.39 & 0.52 & 11.5 & & & & 3.5 & 0.13 & 0.44 & & \\
\hline 1989 & 0 & 0 & 0.72 & 3.39 & 0.52 & 11.5 & & & & 3.5 & 0.13 & 0.44 & & \\
\hline 1990 & 1 & 0 & -0.3 & 3.39 & 0.08 & 11.5 & & & & -1.3 & 0.13 & -0.2 & & \\
\hline 1991 & 1 & 1 & -0.3 & 2.39 & 0.08 & 5.71 & & & & -1.3 & 0.09 & -0.1 & & \\
\hline 1992 & 1 & 3 & -0.3 & 0.39 & 0.08 & 0.15 & & & & -1.3 & 0.01 & -0 & & \\
\hline 1993 & 1 & 0 & -0.3 & 3.39 & 0.08 & 11.5 & & & & -1.3 & 0.13 & -0.2 & & \\
\hline 1994 & 1 & 1 & -0.3 & 2.39 & 0.08 & 5.71 & & & & -1.3 & 0.09 & -0.1 & & \\
\hline 1995 & 1 & 0 & -0.3 & 3.39 & 0.08 & 11.5 & & & & -1.3 & 0.13 & -0.2 & & \\
\hline 1996 & 1 & 0 & -0.3 & 3.39 & 0.08 & 11.5 & & & & -1.3 & 0.13 & -0.2 & & \\
\hline 1997 & 0 & 0 & 0.72 & 3.39 & 0.52 & 11.5 & & & & 3.5 & 0.13 & 0.44 & & \\
\hline 1998 & 0 & 0 & 0.72 & 3.39 & 0.52 & 11.5 & & & & 3.5 & 0.13 & 0.44 & & \\
\hline 1999 & 1 & 1 & -0.3 & 2.39 & 0.08 & 5.71 & & & & -1.3 & 0.09 & -0.1 & & \\
\hline 2000 & 1 & 0 & -0.3 & 3.39 & 0.08 & 11.5 & & & & -1.3 & 0.13 & -0.2 & & \\
\hline 2001 & 0 & 1 & 0.72 & 2.39 & 0.52 & 5.71 & & & & 3.5 & 0.09 & 0.31 & & \\
\hline 2002 & 0 & 0 & 0.72 & 3.39 & 0.52 & 11.5 & & & & 3.5 & 0.13 & 0.44 & & \\
\hline 2003 & 0 & 3 & 0.72 & 0.39 & 0.52 & 0.15 & & & & 3.5 & 0.01 & 0.05 & & \\
\hline 2004 & 1 & 4 & -0.3 & -0.6 & 0.08 & 0.37 & & & & -1.3 & -0 & 0.03 & & \\
\hline 2005 & 0 & 6 & 0.72 & -2.6 & 0.52 & 6.82 & & & & 3.5 & -0.1 & -0.3 & & \\
\hline 2006 & 1 & 4 & -0.3 & -0.6 & 0.08 & 0.37 & & & & -1.3 & -0 & 0.03 & & \\
\hline 2007 & 1 & 4 & -0.3 & -0.6 & 0.08 & 0.37 & & & & -1.3 & -0 & 0.03 & & \\
\hline 2008 & 1 & 3 & -0.3 & 0.39 & 0.08 & 0.15 & & & & -1.3 & 0.01 & -0 & & \\
\hline 2009 & 1 & 5 & -0.3 & -1.6 & 0.08 & 2.6 & & & & -1.3 & -0.1 & 0.08 & & \\
\hline 2010 & 1 & 6 & -0.3 & -2.6 & 0.08 & 6.82 & & & & -1.3 & -0.1 & 0.13 & & \\
\hline 2011 & 1 & 24 & -0.3 & -21 & 0.08 & 425 & & & & -1.3 & -0.8 & 1.03 & & \\
\hline 2012 & 1 & 11 & -0.3 & -7.6 & 0.08 & 57.9 & & & & -1.3 & -0.3 & 0.38 & & \\
\hline 2013 & 1 & 9 & -0.3 & -5.6 & 0.08 & 31.5 & & & & -1.3 & -0.2 & 0.28 & & \\
\hline 2014 & 1 & 17 & -0.3 & -14 & 0.08 & 185 & & & & -1.3 & -0.5 & 0.68 & & \\
\hline 2015 & 1 & 9 & -0.3 & -5.6 & 0.08 & 31.5 & & & & -1.3 & -0.2 & 0.28 & & \\
\hline 2016 & 1 & 5 & -0.3 & -1.6 & 0.08 & 2.6 & & & & -1.3 & -0.1 & 0.08 & & \\
\hline \multirow[t]{2}{*}{2017} & 1 & 3 & -0.3 & 0.39 & 0.08 & 0.15 & & & & -1.3 & 0.01 & -0 & & \\
\hline & 26 & 122 & & & 7.22 & 947 & 36 & 0.21 & 27 & & & 4.1 & 0.12 & 11.7 \\
\hline
\end{tabular}


Table 2. Borehole numbers Vs averaged annual water struck level in the area.

\begin{tabular}{|c|c|c|}
\hline Borehole Year of Commissioning & Borehole No. & Borehole Depth (Average) \\
\hline 1982 & 1 & 204.8 \\
\hline 1985 & 1 & 200 \\
\hline 1991 & 1 & 177 \\
\hline 1992 & 3 & 135 \\
\hline 1994 & 1 & 210 \\
\hline 1999 & 1 & 202 \\
\hline 2001 & 1 & 230 \\
\hline 2003 & 3 & 200.67 \\
\hline 2004 & 4 & 242.5 \\
\hline 2005 & 6 & 287.83 \\
\hline 2006 & 5 & 256 \\
\hline 2007 & 4 & 277.5 \\
\hline 2008 & 3 & 206.4 \\
\hline 2009 & 5 & 292.4 \\
\hline 2010 & 6 & 285.83 \\
\hline 2011 & 24 & 287.38 \\
\hline 2012 & 11 & 298.21 \\
\hline 2013 & 9 & 268.33 \\
\hline 2014 & 17 & 267.71 \\
\hline 2015 & 9 & 290.33 \\
\hline 2016 & 4 & 337.5 \\
\hline 2017 & 3 & 280 \\
\hline
\end{tabular}

things. One the borehole development and investment cost are going up as time passes by. And two, the operational cost in terms of pumping energy is expected to rise in a similar fashion.

\subsection{Plot of Borehole Distribution and Contour Map of Struck Water Levels}

Using the Easting and Northing of each borehole and the water struck level on commission; the contour plot of water rest level was plotted as shown here in Figure 4 and Figure 5.

From the two plots (Figure 4 and Figure 5); contours of struck water level and $100 \mathrm{~m}$ buffer plot of each borehole, we quickly notice the skewed nature of groundwater development in the study area. Most boreholes are in Karen ward. The deep ones are in central and eastern part of Karen. The deepest is at $376 \mathrm{~m}$ and shallowest at $135 \mathrm{~m}$. The $100 \mathrm{~m}$ buffer that currently guides borehole permitting in Kenya has been violated. This has been identified as slight in North West and Central part of Karen ward. The $100 \mathrm{~m}$ buffer limit has been most 


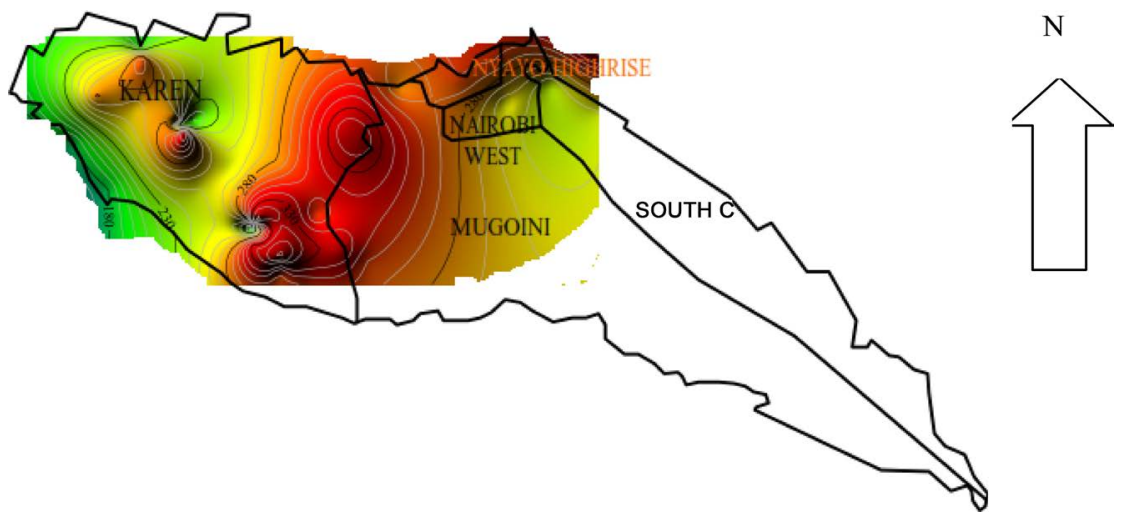

Figure 4. Struck water level contours map over Langata sub County (Not to Scale).

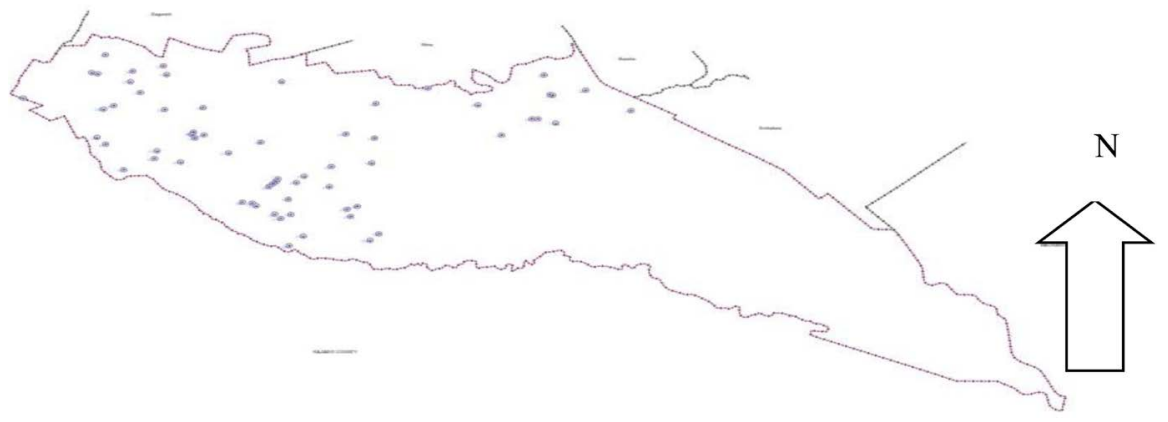

Figure 5. Borehole distribution layout map over Langata sub County (Not to Scale).

prominently violated in the South Eastern part of Karen. The significance of this can be captured if well interference is tested during test pumping.

\section{Conclusions}

Drought exposure risk over Langata sub County has a periodicity cycle of a drought event after every 1.67 years for the period between 1957 and 2013. For each drought event, there was a near $12 \%$ probability of a borehole being drilled in the area. For the specific period with borehole information spanning from 1982 to 2017, a total of 122 boreholes were commissioned translating to nearly 5 boreholes for every drought event. The year 2011 had the severest drought at 1.7 on the SPI scale (see Figure 2) and the most borehole commissioned at 24 (see Figure 3). Most of the borehole development happened in Karen Ward which also hosts the deepest and most dense distribution pattern (see Figure 4 and Figure 5).

From the foregoing, this study concludes that there is a positive correlation coefficient between drought event and borehole drilling in the area. Secondly, there is an upward trend on both borehole numbers and the depth of struck water levels. The increasing numbers have already shown a "syndrome" of high density in terms of $100 \mathrm{~m}$ spatial distance buffer between boreholes, which may already be causing well interference during pumping. This however requires a further test pumping investigation for confirmation. The study confirms that there is a growing tendency to "grab" groundwater in this area. In order to pro- 
mote sustainable groundwater use, the study proposes a formulation new water resource management policy for Nairobi County as a whole. This should by all means endeavor to promote equitable sharing of groundwater resource and be cognizant of the future generation. Recharge program should also be initiated as advised by [95].

\section{Acknowledgements}

The researchers hereby acknowledge the support accorded to them from the Institute for Climate Change \& Adaptation, University of Nairobi, Kenya. They however, declare that this research has not received any funding and as such, each of them, bears no personal interest whatsoever.

\section{Conflicts of Interest}

The authors declare no conflicts of interest regarding the publication of this paper.

\section{References}

[1] Kumar, C.P. (2012) Climate Change and Its Impact on Groundwater Resources. International Journal of Engineering and Science, 1, 43-60.

[2] Taylor, R. (1990) Interpretation of the Correlation Coefficient: A Basic Review. Journal of Diagnostic Medical Sonography, 6, 35-39. https://doi.org/10.1177/875647939000600106

[3] Foster, et al. (2012) Managed Groundwater Development for Water-Supply Security in Sub-Saharan Africa: Investment Priorities. Water, 38, 359-366.

https://doi.org/10.4314/wsa.v38i3.1

[4] Guermazi, E., Milano, M., Reynard, E. and Zairi, M. (2018) Impact of Climate Change and Anthropogenic Pressure on the Groundwater Resources in Arid Environment. Mitigation and Adaptation Strategies for Global Change, 24, 73-92. https://doi.org/10.1007/s11027-018-9797-9

[5] Nair, S.K. (2016) Impact of Climate Change and Anthropogenic Pressure. Proceedings of IAHS, 374, 63-67. https://doi.org/10.5194/piahs-374-63-2016

[6] Foster, S., Hirata, R., Misra, S. and Garduno, H. (2010) Urban Groundwater Use Policy-Balancing the Benefits and Risks in Developing Nations. GW-MATE Strategic Overview Series 3. World Bank, Washington DC. http://www.worldbank.org/gwmate

[7] Marcus, et al. (2012) Managing the Invisible: Understanding and Improving Groundwater Governance. Water Papers, Water Partnership Program, World Bank, Washington DC.

[8] Llamas, M.R. and Martínez-Santos, P. (2005) Intensive Groundwater Use: Silent Revolution and Potential Source of Social Conflicts. American Society of Civil Engineers Journal of Water Resources Planning and Management, 131, 337-341. https://doi.org/10.1061/(ASCE)0733-9496(2005)131:5(337)

[9] Knüppe, K. (2011) The Challenges Facing Sustainable and Adaptive Groundwater Management in South Africa. Water $S A, 37,67-79$. https://doi.org/10.4314/wsa.v37i1.64110

[10] Todd, D.K. (1980) Groundwater Hydrology. John Wiley \& Sons, New York. 
[11] Wilson, C.P.V. (1982) Groundwater Hydrology (2nd edn) by D. K. Todd. Wiley, New York, 1980. 552 pp. Price: $£ 11.00$ (Paperback); £27.35 (Hardback). ISBN 0471 08641 X. Geological Journal, 17, 345. https://doi.org/10.1002/gj.3350170407

[12] Foster, S. (1998) Groundwater: Assessing Vulnerability and Promoting Protection of a Threatened Resource. Proceedings of the 8 th Stockholm Water Symposium, Sweden, 10-13 August 1998, 79-90.

[13] Shiklomanov, I.A. (2000) Appraisal and Assessment of World Water Resources. Water International, 25, 11-32. https://doi.org/10.1080/02508060008686794

[14] Molle, F., López-Gunn, E. and van Steenbergen, F. (2018) The Local and National Politics of Groundwater Overexploitation. Water Alternatives, 11, 445-457.

[15] Shen, D. and Varis, O. (2000) World Water Vision: Balancing Thoughts after the Hague. AMBIO: A Journal of the Human Environment, 29, 523-525. https://doi.org/10.1579/0044-7447-29.8.523

[16] WWAP (2015) Water for a Sustainable World. The United Nations World Water Assessment Programme, UNESCO, Paris.

[17] Gleeson, T., Wada, Y., Bierkens, M.F.P. and van Beek, L.P.H. (2012) Water Balance of Global Aquifers Revealed by Groundwater Footprint. Nature, 488, 197-200. https://doi.org/10.1038/nature11295

[18] Espinosa, et al. (2016) The Dilemma of Groundwater Conservation in Mexico. 2nd World Irrigation Forum, Chiang Mai, 6-8 November 2016, W.1.2.07.

[19] Pavelic, P., Giordano, M., Keraita, B., Ramesh, V. and Rao, T. (2012) Groundwater Availability and Use in Sub-Saharan Africa: A Review of 15 Countries. International Water Management Institute, Colombo. https://doi.org/10.5337/2012.213

[20] Zektser, I.S. (2000) Groundwater and the Environment: Applications for the Global Community. Lewis Publishers, Boca Raton. https://doi.org/10.1201/9781420032895

[21] Wada, Y., van Beek, L.P.H., van Kempen, C.M., Reckman, J.W.T.M., Vasak, S. and Bierkens, M.F.P. (2010) Global Depletion of Groundwater Resources. Geophysical Research Letters, 37, L20402. https://doi.org/10.1029/2010GL044571

[22] Castle, S.L., Thomas, B.F., Reager, J.T., Rodell, M., Swenson, S.C. and Famiglietti, J.S. (2014) Groundwater Depletion during Drought Threatens Future Water Security of the Colorado River Basin. Geophysical Research Letters, 41, 5904-5911. https://doi.org/10.1002/2014GL061055

[23] Shahid, S. and Behrawan, H. (2008) Drought Risk Assessment in the Western Part of Bangladesh. Natural Hazards, 46, 391-413. https://doi.org/10.1007/s11069-007-9191-5

[24] Shahid, S. and Hazarika, M.K. (2009) Groundwater Drought in the Northwestern Districts of Bangladesh. Water Resources Management, 24, 1989-2006. https://doi.org/10.1007/s11269-009-9534-y

[25] Marston, L., Konar, M., Cai, X. and Troy, T.J. (2015) Virtual Groundwater Transfers from Overexploited Aquifers in the United States. Proceedings of the National Academy of Sciences, 112, 8561-8566. https://doi.org/10.1073/pnas.1500457112

[26] Gleick, P.H. and Palaniappan, M. (2010) Peak Water Limits to Freshwater Withdrawal and Use. Proceedings of the National Academy of Sciences, 107, 11155-11162. https://doi.org/10.1073/pnas.1004812107

[27] Seckler, D., Barker, R. and Amarasinghe, U. (1999) Water Scarcity in the Twenty-first Century. International Journal of Water Resources Development, 15, 29-42. https://doi.org/10.1080/07900629948916

[28] Shah, T., Molden, D., Sakthivadivel, R. and Seckler, D. (2000) The Global Ground- 
water Situation: Overview of Opportunities and Challenges. International Water Management Institute, Colombo, 30 p. https://doi.org/10.5337/2011.0051

[29] Postel, S. (1999) Pillar of Sand: Can the Irrigation Miracle Last? Norton, New York.

[30] Xu, Y. and Usher, B. (2006) Groundwater Pollution in Africa. Balkema: Proceedings and Monographs in Engineering, Water and Earth Sciences. Taylor and Francis, London.

[31] Xu, Y. and Braune, E. (2010) Sustainable Groundwater Resources in Africa: Water-Supply and Sanitation Perspective. Engineering and Science, 1, 43-60.

[32] Hoekstra, A.Y., Buurman, J. and van Ginkel, K.C.H. (2018) Urban Water Security: A Review. Environmental Research Letters, 13, Article ID: 053002. https://doi.org/10.1088/1748-9326/aaba52

[33] Konikow, L.F. and Kendy, E. (2005), Groundwater Depletion: A Global Problem. Hydrogeology Journal, 13, 317-320. https://doi.org/10.1007/s10040-004-0411-8

[34] Alley, W.M., Reilly, T.E. and Franke, O.L. (1999) Sustainability of Ground-Water Resources. U.S. Geological Survey Circular, 1186, 79 p. https://doi.org/10.3133/cir1186

[35] Sophocleous, M. (2005) Groundwater Recharge and Sustainability in the High Plains Aquifer in Kansas, USA. Hydrogeology Journal, 13, 351-365. https://doi.org/10.1007/s10040-004-0385-6

[36] Galili, E. and Nir, Y. (1993) The Submerged Pre-Pottery Neolithic Water Well of Atlit-Yam, Northern Israel, and Its Palaeoenvironmental Implications. The Holocene, 3, 265-270. https://doi.org/10.1177/095968369300300309

[37] Brundtland, G.H. (1987) Our Common Future: Report of the World Commission on Environment and Development. UN Document A/42/427, Geneva. http://www.un-documents.net/ocf-ov.htm

[38] Meinzer, O. (1934) The History and Development of Ground-Water Hydrology. Journal of the Washington Academy of Sciences, 24, 6-32. http://www.jstor.org/stable/24532897

[39] Theis, C. (1935) The Relation between the Lowering of the Piezometric Surface and the Rate and Duration of Discharge of a Well Using Groundwater Storage. Transactions, the American Geophysical Union, 16, 519-524. https://doi.org/10.1029/TR016i002p00519

[40] Jacob, C.E. (1950) Flow of Groundwater. In: Rouse, H., Ed., Engineering Hydraulics, Chapter 5, Wiley, New York, 321-386.

[41] Betu, V. (1998) Aquifer Hydraulics: A Comprehensive Guide to Hydro-Geological Data Analysis. John Wiley and Sons, Inc., Hoboken.

[42] Konikow, L.F. (2011) Contribution of Global Groundwater Depletion since 1900 to Sea-Level Rise. Geophysical Research Letters, 38, L17401.

https://doi.org/10.1029/2011GL048604

[43] Cobbing, J.E., Hobbs, P.J., Meyer, R. and Davies, J. (2008) A Critical Overview of Transboundary Aquifers Shared by South Africa. Hydrogeology Journal, 16, 1207-1214. https://doi.org/10.1007/s10040-008-0285-2

[44] Jarvis, W.T. (2006) Transboundary Groundwater: Geopolitical Consequences, Commons Sense, and the Law of the Hidden Sea. PhD Dissertation, University of Oregon, Eugene.

[45] El Naser, H.K. (2009) Management of Scarce Water Resources: A Middle Eastern Experience. WIT Press, London. 
[46] Custodio, E. (2000) The Complex Concept of Over-Exploited Aquifer. Secunda Edicion, Uso Intensivo de Las Agua Subterráneas, Madrid.

[47] Foster, S., Tuinhof, A., Kemper, K., Garduno, H. and Nanni, M. (2003) Characterization of Groundwater Systems-Key Concepts and Frequent Misconceptions.

[48] Simmers, I., Hendriks, J.M.H., Kruseman, G.P. and Rushton, K.R. (1997) Recharge of Phreatic Aquifers in Semi-Arid Areas: IAH International Contributions to Hydrogeology 19. CRC Press, London.

[49] Lerner, D.N., Issar, A.S. and Simmers, I. (1990) Groundwater Recharge: A Guide to Understanding and Estimating Natural Recharge (Volume 8, International Contributions to Hydrogeology). Heise, Hanover.

[50] Caro, R. and Eagleson, P.S. (1981) Estimating Aquifer Recharge Due to Rainfall. Journal of Hydrology, 53, 185-211. https://doi.org/10.1016/0022-1694(81)90001-9

[51] Lloyd, J.W. (2002) Groundwaters in Regional Arid Basins and Their Semiarid Margins. Problematica de la gestion de las agues en regions semiaridas, Communidad de Valencia, $12 \mathrm{p}$.

[52] Manfred, S. (2005) The Universal Destination of Goods-The Ethics of Property in the Theory of a Christian Society. Journal of Markets and Morality, 8, 333-354.

[53] Heath, T. (2010) Kenya Climate Change Briefing. Water and Sanitation for the Urban Poor WSUP, London, $4 \mathrm{p}$.

[54] Ochungo, et al. (2018) Water Supply Security in a Drought Exposed Nairobi: Adopting a Blockchain Provenance Tracking for Informal Alternatives. The International Journal of Innovative Research in Science, Engineering and Technology, 7, 10475-10483.

[55] Mulwa, J.K., Gaciri, S.J., Barongo, J.O., Opiyo-Aketch, N. and Kianji, G.K. (2005) Geological and Structural Influence on Groundwater Distribution and Flow in Ngong Area, Kenya. Africa Journal of Science and Technology, Science and Engineering Series, 6, 105-115. https://doi.org/10.4314/ajst.v6i1.55166

[56] Ayibotele, N.B. (1992) The World's Water: Assessing the Resource. International Conference on Water and the Environment: Development Issues for the 21 st Century, Dublin, 26-31 January 1992, 1.1-1.26.

[57] Chepyegon, C. and Kamiya, D. (2018) Challenges Faced by the Kenya Water Sector Management in Improving Water Supply Coverage. Journal of Water Resource and Protection, 10, 85-105. https://doi.org/10.4236/jwarp.2018.101006

[58] Ondigo, D.A., Kavoo, A.M. and Kebwaro, J. (2018) Water Resources and Management under Increasing Urban Demography: A Kenyan Perspective-A Review. Journal of Water Resource and Protection, 10, 919-938. https://doi.org/10.4236/jwarp.2018.109054

[59] Gavaerts, E.A.L. (1964) Hydrogeology of the Nairobi Area. Tech. Rep. No. 1, Water Development Department.

[60] Onyancha, C.K., Mathu, E.M., Mwea, S.K. and Ngecu, W.M. (2012) Variation of Groundwater Static Levels in Nairobi City since 1927 and Its Social Implications.

[61] Ichangi, D. (n.d) Vulnerability of Nairobi Basin Aquifers Due to Over Abstraction of Ground Water. http://geology.uonbi.ac.ke/node/983

[62] Mogaka, H., Gichere, S., Davis, R. and Hirji, R. (2005) Climate Variability and Water Resource Degradation in Kenya-Improving Water Resources Development and Management. World Bank Working Paper Series No. 69, World Bank, Washington DC. (In English) https://doi.org/10.1596/978-0-8213-6517-5

[63] Mumma, A., Lane, M., Kairu, E., Tuinhof, A. and Hirji, R. (2011) Kenya: Ground- 
water Governance Case Study. Water Papers, World Bank, Washington DC. (In English)

[64] Foster, S. and Tuinhof, A. (2005) Kenya: The Role of Groundwater in the Water-Supply of Greater Nairobi. GW, MATE Case Profile Collection. The World Bank, Washington DC, No. 13, 6 p.

[65] Simiyu, N.L. and Dulo, S.O. (2015) Spatiotemporal Analysis of Borehole Locations in Nairobi County 1930-2013. International Journal of Application or Innovation in Engineering and Management, 4, 230-238.

[66] Wayumba, G.O. (2001) Modelling Potential Disaster Sites for City of Nairobi, Kenya. International Conference on Spatial Information for Sustainable Development, Nairobi, 2-5 October 2001, 1-11.

[67] Menzer, O.E., Kelton, F.C. and Forbes, R.H. (1913) Geology and Water Resources of Sulfer Springs Valley, Arizona, with a Section on Agriculture. Water Supply Paper No. 320.

[68] Martin, W.E. and Archer, T. (1971) Cost of Pumping Irrigation Water in Arizona: 1891 to 1967. Water Resources Research, 7, 23-31. https://doi.org/10.1029/WR007i001p00023

[69] Tellman, B., Bausch, J.C., Eakin, H., Anderies, J.M., Mazari-Hiriart, M., Manuel-Navarrete, D. and Redman, C.L. (2018) Adaptive Pathways and Coupled Infrastructure: Seven Centuries of Adaptation to Water Risk and the Production of Vulnerability in Mexico City. Ecology and Society, 23, 1. https://doi.org/10.5751/ES-09712-230101

[70] Raskin, P., Hansen, E. and Margolis, R. (1995) Water and Sustainability. A Global Outlook. Polestar, Series No. 4, Stockholm Environment Institute, Stockholm, 66 p.

[71] Shamsudduha, M., Taylor, R.G., Ahmed, K.M. and Zahid, A. (2011) The Impact of Intensive Groundwater Abstraction on Recharge to a Shallow Regional Aquifer System: Evidence from Bangladesh. Hydrogeology Journal, 19, 901-916. https://doi.org/10.1007/s10040-011-0723-4

[72] Ashraf, B., AghaKouchak, A., Alizadeh, A., Mousavi Baygi, M.R., Moftakhari, H., Mirchi, A., Madani, K., et al. (2017) Quantifying Anthropogenic Stress on Groundwater Resources. Scientific Reports, 7, Article No. 12910.

https://doi.org/10.1038/s41598-017-12877-4

[73] AghaKouchak, A., Feldman, D., Hoerling, M., Huxman, T. and Lund, J. (2015) Water and Climate: Recognize Anthropogenic Drought. Nature, 524, 409-411. https://doi.org/10.1038/524409a

[74] Mukherji, A. and Shah, T. (2005) Groundwater Socio-Ecology and Governance: A Review of Institutions and Policies in Selected Countries. Hydrogeology Journal, 13, 328-345. https://doi.org/10.1007/s10040-005-0434-9

[75] Yan, Z. (2002) Sustainable Groundwater Development and Management in the Quaternary Hang-Jia-Hu Plain, China. Journal of Zhejiang University Science, 3, 205-208. https://doi.org/10.1631/jzus.2002.0205

[76] Diamond, J. (2005) Collapse: How Societies Choose to Fail or Succeed. Viking, New York.

[77] Hunt, T.L. and Lipo, C.P. (2012) Ecological Catastrophe and Collapse: The Myth of "Ecocide" on Rapa Nui (Easter Island). PERC Research Paper No. 12/3. https://doi.org/10.2139/ssrn.2042672

[78] Leech, B. (2011) Boom, Bust, and the Berkeley Pit: How Insiders and Outsiders Viewed the Mining Landscape of Butte, Montana. IA. The Journal of the Society for 
Industrial Archeology, 37, 153-170. http://www.jstor.org/stable/23757914

[79] Kerr, R.A. (1991) Geothermal Tragedy of the Commons. Science, 253, 134-135. https://doi.org/10.1126/science.253.5016.134

[80] Massuel, S. and Riaux, J. (2017) Groundwater Overexploitation: Why Is the Red Flag Waved? Case Study on the Kairouan Plain Aquifer (Central Tunisia). Hydrogeology Journal, 25, 1607-1620. https://doi.org/10.1007/s10040-017-1568-2

[81] Sappa, G. and Rossi, M. (2010) Local Effects of Groundwater Overexploitation of the Complex Terminal in NWSAS.

[82] Reddy, V.R. (2005) Costs of Resource Depletion Externalities: A Study of Groundwater Overexploitation in Andhra Pradesh, India. Environment and Development Economics, 10, 533-556. https://doi.org/10.1017/S1355770X05002329

[83] Chen, Y. and Shu, L.C. (2012) Vulnerability Assessment of Land Subsidence Induced by Groundwater Overexploitation: A Case of Xixi-Chengnan Area in Jiangsu Province. Advanced Materials Research, 518-523, 4321-4324. https://doi.org/10.4028/www.scientific.net/AMR.518-523.4321

[84] Faisal, I.M., Parveen, S. and Kabir, M.R. (2005) Sustainable Development through Groundwater Management: A Case Study on the Barind Tract. International Journal of Water Resources Development, 21, 425-435. https://doi.org/10.1080/07900620500160800

[85] Sun, W. and Ren, J.M. (2012) Research of Water Resources Sustainable Utilization and Its Effect on the Development of Regional Economy. Advanced Materials Research, 518-523, 4346-4349.

https://doi.org/10.4028/www.scientific.net/AMR.518-523.4346

[86] Muller, M. (2007) Adapting to Climate Change: Water Management for Urban Resilience. Environment and Urbanization, 19, 99-113. https://doi.org/10.1177/0956247807076726

[87] Vrba, J. and Zaporozec, A. (1994) Guidebook on Mapping Groundwater Vulnerability. International Contributions to Hydrogeology, Vol. 16, Verlag Heinz Heise, Hannover, $131 \mathrm{p}$.

[88] Amfo-Otu, R., Agyenim, J. and Buddy Nimba-Bumah, G. (2014) Correlation Analysis of Groundwater Colouration from Mountainous Areas, Ghana. Environmental Research, Engineering and Management, 1, 16-24.

https://doi.org/10.5755/j01.erem.67.1.4545

[89] McKee, T.B., Doesken, N.J. and Kleist, J. (1993) The Relationship of Drought Frequency and Duration to Time Scales. Proceedings of the 8 th Conference on Applied Climatology, Anaheim, 17-22 January 1993, 179-184.

[90] Hayes, M.J., Svoboda, M.D., Wall, N. and Widhalm, M. (2011) The Lincoln Declaration on Drought Indices: Universal Meteorological Drought Index Recommended. Bulletin of the American Meteorological Society, 92, 485-488. https://doi.org/10.1175/2010BAMS3103.1

[91] Taylor, R. (1990) Interpretation of the Correlation Coefficient: A Basic Review. Journal of Diagnostic Medical Sonography, 6, 35-39. https://doi.org/10.1177/875647939000600106

[92] Helsel, D.R. and Hirsch, R.M. (2002) Statistical Methods in Water Resources, Book 4, Hydrologic Analysis and Interpretation. US Geological Survey, Richmond, 510 p.

[93] Pallant, J. (2011) SPSS Survival Manual: A Step by Step Guide to Data Analysis Using SPSS. Fourth Edition, Allen and Unwin, Australia.

[94] Ezezue, et al. (2017) Distribution of Boreholes in Residential Layouts and Implica- 
tions for Planning of Awka, Nigeria. Mgbakoigba, Journal of African Studies, 7, 156-166.

[95] Mwaura, G. (2015) Possible Artificial Groundwater Recharge Zone for Nairobi Aquifer(s). 